\title{
Size-related changes in vulnerability to predators and spatial refuge use by juvenile Iceland scallops Chlamys islandica
}

\author{
David J. Arsenault*, John H. Himmelman \\ GIROQ and Département de Biologie, Université Laval, Québec (Québec), Canada G1K 7P4
}

\begin{abstract}
We examined size-related changes in vulnerability of juvenile Iceland scallops Chlamys islandica to crab and asteroid predators using field experiments in the Mingan Islands, northern Gulf of St. Lawrence, eastern Canada. Vulnerability to both crabs and asteroids markedily decreased with scallop size, likely because of increases in the effectiveness of the scallop's antipredator defenses. Multiple-choice experiments showed that the crabs Hyas araneus and Cancer irroratus preyed mainly upon small scallops (10 to $30 \mathrm{~mm}$ ). At our study site $H$ araneus was the most abundant decapod and was likely the major predator of scallops. Small lceland scallops were generally found in crevices. byssally attached to the undersides of dead shells and rocks. Use of these refuges did not show diel periodicity but decreased markedly with scallop size, attaining $0 \%$ for $>60 \mathrm{~mm}$ scallops. Tethering experiments indicated that refuge use decreased vulnerability to both crabs and asteroids. However, the advantage of refuge use, in terms of reduced predation risk, varied with scallop size, being maximal for 15 to $30 \mathrm{~mm}$ scallops and only marginal for larger, less vulnerable scallops.
\end{abstract}

KEY WORDS: Chlamys islandica Scallop Predation Vulnerability $\cdot$ Size $\cdot$ Refuge

\section{INTRODUCTION}

Predation is thought to be a major selective force acting upon prey populations because of its direct effect on local survival and further because it favours the development of antipredator defenses (Sih 1985, 1987). The latter fall into 2 categories based on whether the defensive mechanism used by prey acts before or following encounters with predators (Sih 1987, Lima \& Dill 1990). Escape responses are exhibited following encounters and decrease the probability of being captured or consumed by predators, whereas predator avoidance occurs before encounters and decreases the probability of being detected. As predation risk generally changes with prey size, the intensity of antipredator defenses may be adjusted during ontogeny (Sih 1987, Lima \& Dill 1990).

Studies on antipredator defenses in scallops (Bivalvia: Pectinidae) have mainly focused on escape re-

•E-mail: arsen@atlas.odyssee.net sponses such as flight and passive escape provided by shell morphology (Brand 1991, Barbeau \& Scheibling 1994a). Flight, elicited by attacks from asteroids (Thomas \& Gruffydd 1971, Barbeau \& Scheibling 1994a) and gastropods (Winter \& Hamilton 1985), is achieved by rapid valve closure which propels the scallop away from the predator (Brand 1991). In contrast, the response of scallops to attacks by decapods usually involves valve closure (Barbeau \& Scheibling 1994a) and escape depends on morphological traits, such as shell strength or shape, which decrease the probability of consumption by reducing handling efficiency (Juanes 1992). Predator avoidance has only been documented in juvenile bay scallops Argopecten irradians which escape from epibenthic predators by attaching to elevated positions on eelgrass blades (Pohle et al. 1991).

The Iceland scallop Chlamys islandica (O. F. Müller) is a sub-Arctic species found along the coasts of Norway, Iceland, Greenland and eastern Canada (Ekman 1953). It is generally found byssally attached to coarse 
substrata in areas with strong tidal currents (Wiborg 1963, Arsenault \& Himmelman 1996). As with other scallops (Lake \& Jones 1987, Barbeau \& Scheibling 1994a), small C. islandica are highly vulnerable to predators, especially decapods (Arsenault \& Himmelman 1996). Evidence of a predator avoidance behaviour has been reported in juvenile Iceland scallops ( $<60 \mathrm{~mm}$ shell height) in the Mingan Islands, eastern Canada (Arsenault \& Himmelman 1996). Small scallops are found mostly in crevices, generally attached to the undersides of dead shells or rocks. Use of these refuges becomes less frcquent as vulnerability to predators decreases with increasing scallop size, suggesting an ontogenetic microhabitat shift related to predation risk. We therefore hypothesized that refuge use by small Iceland scallops decreases their vulnerability to predators and that the advantage of this avoidance behaviour decreases as their vulnerability to predators decreases with increasing size.

Our study examines: (1) size-selectivity in the foraging of the crabs Hyas araneus and Cancer irroratus, (2) size-related variations in the frequency of refuge use and (3) the effect of refuge use on vulnerability of different sized scallops to predation by crabs and asteroids.

\section{METHODS}

Study area. We studied a population of the Iceland scallop Chlamys islandica at Île du Fantôme, Mingan Islands, northern Gulf of St. Lawrence, eastern Canada $\left(50^{\circ} 13^{\prime} 6^{\prime \prime} \mathrm{N}, 63^{\circ} 41^{\prime} 12^{\prime \prime} \mathrm{W}\right)$. In this area, small juveniles $(<30 \mathrm{~mm})$ are mainly found in shallow water $(15 \mathrm{~m})$ whereas larger individuals predominate at greater (>25 m) depths (Arsenault \& Himmelman 1996). Scallops of small size generally occupy crevices under shells of the bivalve Spisula polynyma. Potential predators of scallops at île du Fantôme include the crabs Hyas araneus and Cancer irroratus and the asteroids Leptasterias polaris, Crossaster papposus and Asterias vulgaris.

Size-related changes in vulnerability to crab predators. We examined size-related changes in vulnerability to crabs using field experiments in which individual Hyas araneus (97 $\pm 1 \mathrm{~mm}$ carapace length, $\bar{x} \pm \mathrm{SE}$ ) and Cancer irroratus (115 $\pm 2 \mathrm{~mm}$ carapace width, $\bar{x} \pm \mathrm{SE}$ ) were provided with 5 scallops of each of 3 size groups (10 to 30,30 to 60 and 60 to $90 \mathrm{~mm}$ in shell height) in $1 \times 1 \times 0.5 \mathrm{~m}$ cages. After $7 \mathrm{~d}$, we recorded the proportion of scallops which had been preyed upon in each size group. Control trials, in which scallops were placed in cages without crabs, were performed to assess manipulation-induced mortality. A total of 19,9 and 2 trials were run for $H$. araneus, $C$. irroratus and the control respectively. Because the consumption of different food types in multiple-choice experiments are likely not independent if predators exhibit preference, use of univariate statistical procedures such as ANOVAs are inappropriate (Roa 1992). Therefore, we used Quade's $T_{1}$ non-parametric test (Roa 1992) to analyze size-related changes in vulnerability of scallops to both crab predators.

Diel periodicity in size-specific refuge use by scallops. Prey often show diel periodicity in activity when foraging of predators is concentrated during specific periods of the day (Flecker 1992, Williamson 1993, Tikkanen et al. 1994). Crabs are known to exhibit diel periodicity in their foraging (Bérubé 1989, Sponaugle \& Lawton 1990). Thus, we compared the frequency of refuge use by different sized scallops during the day and night. Using SCUBA, we sampled quadrats of $0.25 \mathrm{~m}^{2}$ during the daytime (06:00 to $17: 00 \mathrm{~h}, \mathrm{n}=165$ ) and nighttime (22:00 to $02: 00 \mathrm{~h}, \mathrm{n}=130)$, and noted for each scallop encountered its size and whether it was exposed or in a crevice. The effects of scallop size (5 groups: 0 to 15,15 to 30,30 to 45,45 to 60 and $>60 \mathrm{~mm}$ ) and time (day or night) on the frequency of crevice use were analyzed using $\chi^{2}$ tests (Zar 1984). We further determined if the effect of time varied with scallop size (interaction between time and scallop size) using a heterogeneity $\chi^{2}$ test (Zar 1984). Because some of the expected values were $<1$, calculated $\chi^{2}$ values were likely biased (Zar 1984). Therefore, we compared the calculated $\chi^{2}$ values to the frequency distributions of $\chi^{2}$ values obtained by randomly assigning the data 10000 times to each factor combination (scallop size + time). From these randomization distributions, we determined the probability of obtaining $\chi^{2}$ values equal to or greater than those observed under the null hypothesis of absence of size and time effects (see Manly 1991 for a comprehensive presentation of randomization methods).

Effect of refuge use on size-specific vulnerability to predators. To evaluate the effect of refuge use on size-specific vulnerability to predators, experiments were performed using tethered scallops of 3 size classes (15 to 30,30 to 45 and 45 to $60 \mathrm{~mm}$ in shell height) during the summer of 1994. Groups of $10 \mathrm{scal}$ lops per size class were tethered to $50 \mathrm{~cm}$ long monofilament threads (exposed) and to the undersides of Spisula polynyma shells using a $<1 \mathrm{~cm}$ tether (sheltered). Scallops of the 6 different treatment combinations ( 3 sizes + exposed or not) were randomly distributed at $1 \mathrm{~m}$ intervals along transects at $15 \mathrm{~m}$ in depth. All potential refuges in the vicinity of exposed scallops were removed prior to the experiment so that they could not seek refuge. A control trial was concurrently performed to assess experimentally induced mortality (bias). For each size group, we placed 10 
tethered scallops in $50 \times 50 \times 15 \mathrm{~cm}$ predator exclusion cages. After $14 \mathrm{~d}$, we noted whether scallops were living or dead, and in the latter case, whether the valves were crushed or intact. Crushed valves were assumed to result from decapod predation and intact valves from asteroid predation or other sources of mortality (Barbeau et al. 1994, Stokesbury \& Himmelman 1995). Vulnerability to predators was calculated as the proportion of scallops which had been preyed upon by each predator group. We adjusted these values for non-predatory mortality by subtracting the proportion of mortality of similar type (crushed or intact valves) observed in the control. The experiment was replicated 5 times at $\sim 1$ wk intervals from early June to late July 1994. The effects of scallop size and exposure (exposed or sheltered) on vulnerability to decapod and asteroid predators were analyzed using randomized block factorial ANOVAs with replicates as the blocking factor. The data were not transformed since assumptions of homogeneity of variances and normality were not violated (Hartley's $F_{\max }$ test, $p>0.05$; Shapiro-Wilks test, $p>0.05$ ). Significant interactions were further analyzed using simple maineffects tests (Kirk 1982) which specifically tested the effect of scallop size for each exposure level (exposed or sheltered) and the effect of exposure for each scallop size. The error rate $(\alpha)$ for these tests was adjusted using the Dunn-Bonferroni procedure at $\alpha^{\prime}=0.032$ (Kirk 1982).

We evaluated the density of potential predators during the first, third and fifth tethering trials by sampling 30 quadrats of $4 \mathrm{~m}^{2}$. Variations in predator density during our tethering experiments were analyzed using separate Kruskal-Wallis tests for each predator species (Zar 1984)

\section{RESULTS}

\section{Size-related changes in vulnerability to crab predators}

Vulnerability to both Hyas araneus and Cancer irroratus varied markedly with scallop size $\left(T_{1}=20.04, \mathrm{p}<\right.$ 0.0001 for $H$. araneus and $T_{1}=14.44, \mathrm{p}<0.0001$ for $C$. irroratus) as both crabs preferentially preyed upon small scallops (Fig. 1). The feeding rate of $H$. araneus was greater than for $C$. irroratus. Further, the less abrupt decrease in vulnerability between 10 to 30 and 30 to $60 \mathrm{~mm}$ scallops for $H$. araneus ( 2 -fold, 58 to $28 \%$ ), compared to $C$. irroratus (4-fold, 29 to $7 \%$ ), indicated that its foraging was less selective. That scallops $>60 \mathrm{~mm}$ were never preyed upon suggests that they had reached a size refuge from both crabs. No mortalities occurred in the control trials.

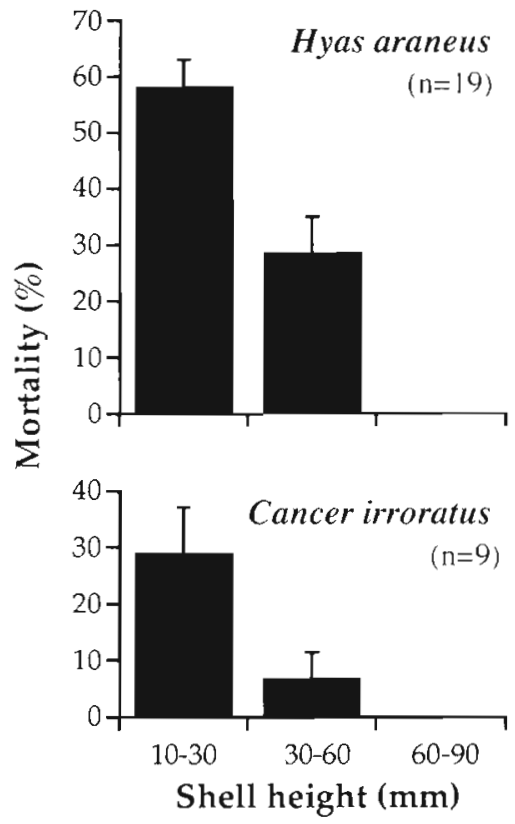

Fig. 1. Chlamys islandica. Size-related vulnerability of Iceland scallops to predation by the crabs Hyas araneus and Cancer irroratus as determined in multiple-choice experiments in cage enclosures during summer 1992 at Île du Fantôme, Mingan Islands

\section{Diel periodicity in size-specific refuge use by scallops}

The frequency of refuge use decreased markedly with increasing scallop size $\left(\chi^{2}=328.95, p<0.00001\right.$, Fig. 2). That neither time (day or night), nor the interaction between time and scallop size were significant $\left(\chi^{2}=1.15, p=0.29\right.$ and $\chi^{2}=2.25, p=0.69$, respectively) indicated a lack of diel periodicity in refuge use by scallops of all sizes (Fig. 2).

\section{Effect of refuge use on size-specific vulnerability to predators}

Vulnerability to both decapod and asteroid predators varied with the degree of exposure of the scallops (Table 1, Fig. 3). The effect of scallop size on vulnerability was only significant for decapod predators, likely because of opposite trends in the vulnerability of exposed and sheltered scallops to asteroid predators (Table 1, Fig. 3). The significant interactions between scallop size and exposure indicated that the effect of refuge use on vulnerability to both decapod and asteroid predators varied with scallop size (Table 1). The simple main-effect tests showed that use of refuges decreased vulnerability to decapod and asteroid predators for 15 to $30 \mathrm{~mm}$ scallops but not for larger 


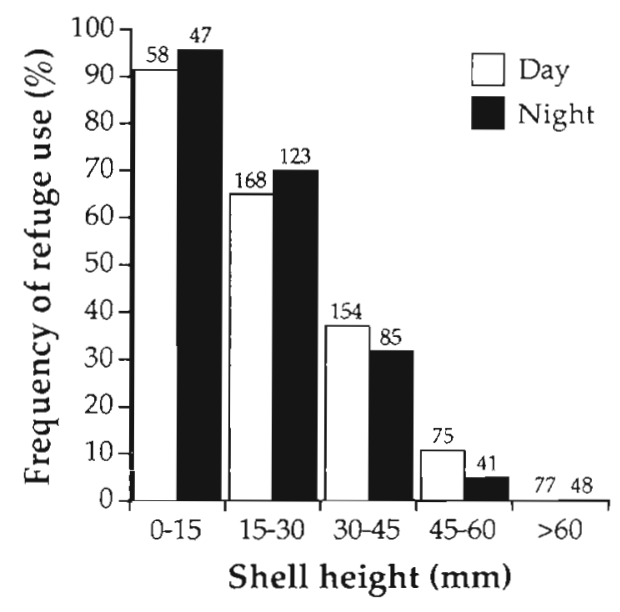

Fig. 2. Chlamys islandica. Size-related variation in the proportion of Iceland scallops in spatial refuges during the day and night at Île du Fantôme during summer 1994. Values above bars indicate the number of observations

scallops (Table 2). Further, vulnerability to both decapod and asteroid predators decreased with increasing size for exposed scallops but not for sheltered scallops (Table 2). Mortality of tethered scallops in the predator exclusion cages was low $(3.3 \pm 1.3 \%, \bar{x} \pm \mathrm{SE})$ and did not vary among size classes (ANOVA, $F_{2,12}=0.25, \mathrm{p}=$ 0.78). All dead scallops had intact valves.

The density of potential predators did not vary during our tethering trials (Table 3 ). Leptasterias polaris and Crossaster papposus were the most abundant asteroids. Their density was about 3 times greater than that of $A s-$ terias vulgaris (Table 3). Hyas araneus was the only decapod found in our samples, however, the rock crab Cancer irroratus and the snow crab Chinocetes opilio were occasionally observed during the summer.

Table 1. Chlamys islandica. Summary of randomized block factorial ANOVAs relating the proportion of Iceland scallops which were preyed upon by decapods or asteroids to scallop size and exposure (exposed or sheltered) as determined by tethering trials at ille du Fantôme during summer 1994. The blocks correspond to replicate experiments $(n=5)$

\begin{tabular}{|lrrrr|}
\hline Source of variation & df & MS & $F$ & $p$ \\
\hline Decapods & & & & \\
Blocks & 4 & 0.015 & 1.44 & 0.26 \\
Size & 2 & 0.073 & 7.23 & 0.004 \\
Exposure & 1 & 0.108 & 10.69 & 0.004 \\
Size $\times$ exposure & 2 & 0.037 & 3.66 & 0.044 \\
Residual & 20 & 0.010 & & \\
Asteroids & & & & \\
Blocks & 4 & 0.006 & 0.91 & 0.48 \\
Size & 2 & 0.010 & 1.61 & 0.23 \\
Exposure & 1 & 0.056 & 8.76 & 0.008 \\
Size $\times$ exposure & 2 & 0.026 & 4.09 & 0.032 \\
Residual & 20 & 0.006 & & \\
\hline
\end{tabular}

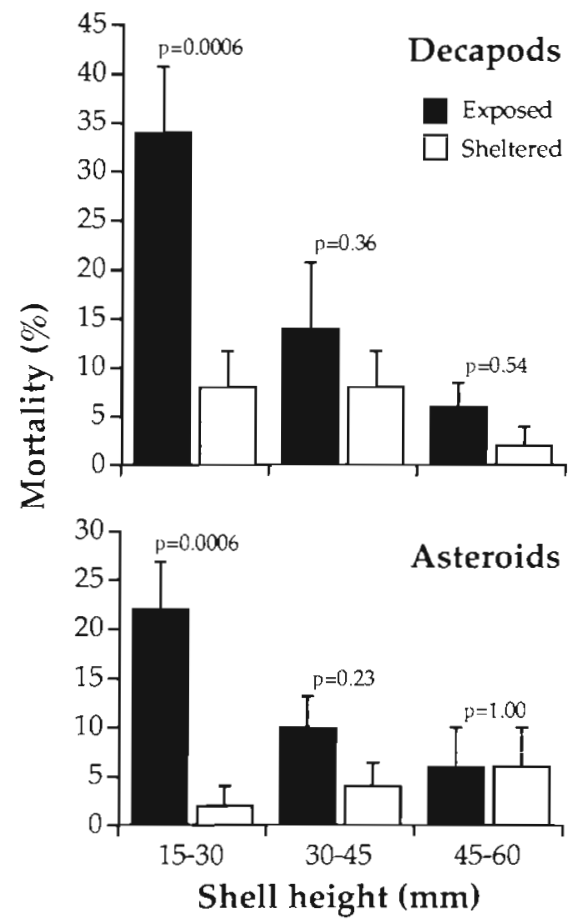

Fig. 3. Chlamys islandica. Size-related variations in vulnerability to decapod and asteroid predators of juvenile Iceland scallops on exposed surfaces and sheltered underneath bivalve shells as determined from tethering trials $(\mathrm{n}=5)$ at $15 \mathrm{~m}$ depth, at Île du Fantôme during summer 1994. Probability values are from simple main-effect tests comparing the mortality of exposed and sheltered scallops for each scallop size class

\section{DISCUSSION}

\section{Size-specific vulnerability to crab and asteroid predators}

Vulnerability of juvenile Iceland scallops to predation by the crabs Cancer irroratus and Hyas araneus markedly decreases with increasing scallop size suggesting that they attain a size refuge from these decapods (Figs. 1 \& 3). This is consistent with the general pattern of decreasing vulnerability with increasing prey size reported for decapods preying upon molluscs (Juanes 1992). Scallops generally respond to encounters with crabs by closing their valves rather than by fleeing (Barbeau \& Scheibling 1994a, Arsenault pers. obs.), behaviour thought to be elicited by the detection of fast moving objects by image-forming eyes on the scallop's mantle edge (Wilkens 1991). Escaping attacks from decapods likely depends on the willingness and ability of the decapod to crush the scallop's valves. Size refuges attained by molluscan prey from decapod predators are generally attributable to changes in shell morphology (such as strength 
Table 2. Chlamys landica. Summary table of simple maineffect tests used to analyze significant interactions between exposure (exposed or sheltered) and scallop size indicated by randomized block factorial ANOVAs testing the effects of exposure and scallop size on vulnerability of Iceland scallops to decapod and asteroid predators (Table 1), as determined using tethering trials at l̂le du Fantôme during summer 1994

\begin{tabular}{|llrrl|}
\hline \multicolumn{2}{l}{ Source of variation } & $\mathrm{df}$ & $F$ & $\mathrm{p}$ \\
\hline Decapods & & & & \\
Exposure & $15-30 \mathrm{~mm}$ & 1,20 & 16.73 & 0.0006 \\
& $30-45 \mathrm{~mm}$ & 1,20 & 0.89 & 0.36 \\
& $45-60 \mathrm{~mm}$ & 1,20 & 0.40 & 0.54 \\
Scallop size & Exposed & 2,20 & 10.30 & 0.0008 \\
& Sheltered & 2,20 & 0.59 & 0.56 \\
Asteroids & & & & \\
Exposure & $15-30 \mathrm{~mm}$ & 1,20 & 16.67 & 0.0006 \\
& $30-45 \mathrm{~mm}$ & 1,20 & 1.50 & 0.23 \\
& $45-60 \mathrm{~mm}$ & 1,20 & 0.00 & 1.00 \\
Scallop size & Exposed & 2,20 & 5.78 & 0.01 \\
& Sheltered & 2,20 & 0.33 & 0.72 \\
& & & & \\
\hline
\end{tabular}

Table 3. Chlamys islandica. Mean density of potential predators of Iceland scallops at Île du Fantôme as determined from sampling of 90 quadrats of $4 \mathrm{~m}^{2}$, during summer 1994. Values of $H$ and $p$ are from Kruskal-Wallis tests comparing the density of the different predators for the 3 sampling dates during tethering trials

\begin{tabular}{|lccc|}
\hline Potential predators & $\begin{array}{c}\left.\text { Density (ind. } 4 \mathrm{~m}^{-2}\right) \\
(\overline{\mathrm{x}} \pm \mathrm{SE})\end{array}$ & $H$ & $\mathrm{p}$ \\
\hline $\begin{array}{l}\text { Decapods } \\
\text { Hyas araneus }\end{array}$ & $0.81 \pm 0.12$ & 4.00 & 0.14 \\
Cancer irroratus & $0.00 \pm 0.00$ & - & - \\
Asteroids & & & \\
Leptasterias polaris & $0.73 \pm 0.09$ & 0.81 & 0.67 \\
Crossaster papposus & $0.67 \pm 0.08$ & 0.50 & 0.78 \\
Asterias vulgaris & $0.27 \pm 0.07$ & 1.74 & 0.42 \\
\hline
\end{tabular}

or shape) which render them difficult to crush because of mechanical limitations of decapod chelae (Juanes 1992). C. irroratus has long been recognized as a major predator of scallops in the northwestern North Atlantic Ocean (Elner \& Jamieson 1979, Barbeau \& Scheibling 1994a, Stokesbury \& Himmelman 1995). Although $H$. araneus has previously been considered a potential predator of Iceland scallops by Gilkinson \& Gagnon (1991), our study is the first to quantify size-specific vulnerability of $C$. islandica to this predator. Both $C$. irroratus and $H$. araneus occur at depths where juvenile scallops are found at Île du Fantôme (Arsenault \& Himmelman 1996). However, C. irroratus is markedly less abundant than $H$. araneus and is mostly found in the sandy zone in shallower water $(<10 \mathrm{~m})$. That only
$H$. araneus was observed in our quadrat sampling, suggests that it is likely the most important decapod predator of scallops at Île du Fantôme and may be largely responsible for the crushed valves in our tethering experiment.

Vulnerability to asteroids also decreased with increasing scallop size (Fig. 3). A similar pattern was observed by Barbeau \& Scheibling (1994a) for juvenile Placopecten magellanicus being preyed upon by Asterias vulgaris. Scallops actively escape predatory asteroids by swimming away (Brand 1991, Barbeau \& Scheibling 1994a), a behaviour elicited by tactile and chemical stimulation of sensory tentacles located on the mantle velum (Wilkens 1991). The decreasing vulnerability to asteroids with increasing scallop size likely results from size-related increases in the effectiveness of the scallop's flight response since swimming distance and speed generally increase with scallop size (Winter \& Hamilton 1985, Manuel \& Dadswell 1991, Barbeau \& Scheibling 1994a). Our data did not allow us to identify which asteroid species preyed upon scallops. However, we suspect that Leptasterias polaris was the predominant asteroid predator since it was frequently observed preying on scallops during numerous dives at Île du Fantôme from 1990 to 1995. Only a few instances of $A$. vulgaris and Crossaster papposus preying upon scallops were encountered. For the former, this was because of its low abundance whereas the latter was abundant but preyed mostly on green sea urchins. L. polaris was the predator in all of 8 predations by asteroids which were observed during our tethering trials.

\section{Effect of refuge use on vulnerability to predators}

Our tethering experiment indicated that refuge use by scallops decreased vulnerability to both crab and asteroid predators (Fig. 3). Because the effectiveness of the scallop's escape responses to these predators likely increases with scallop size (Juanes 1992, Barbeau \& Scheibling 1994a), small and vulnerable individuals should benefit more from avoiding encounters with predators than larger and less vulnerable individuals. Our tethering experiments support this hypothesis since the advantage of refuge use, in terms of reduced predation risk, was maximal for 15 to $30 \mathrm{~mm}$ scallops and only marginal for larger scallops (Fig. 3).

Crabs are rapid-moving predators that search for prey using chemical, tactile and visual stimuli (Land 1984, Zimmer-Faust 1989). The high vulnerability of small scallops to crab predators, due to the inefficiency of their escape response (valve closure), led Barbeau \& Scheibling (1994a) to hypothesize that encounter rate is likely the major factor determining crab predation 
rates in nature. Use of crevices by small Iceland scallops likely decreases encounters with crabs by reducing the probability of being detected. Crevice use may also protect scallops from other visual predators such as eider ducks (Brun 1971) and fish. Asteroids, in contrast to the above predators, are slow-moving, nonvisual predators which usually use chemodetection to search for prey (SIoan \& Campbell 1982, Rochette et al. 1994). Crevice use may also render Iceland scallops more difficult to detect by asteroids because odour plumes originating from scallops in crevices are likely weaker and distorted by turbulence near the bottom (Weissburg \& Zimmer-Faust 1993).

Several types of bias can affect estimates of predation rates based on tethering experiments (Barbeau \& Scheibling 1994b, Peterson \& Black 1994, ZimmerFaust et al. 1994). Biases generally arise from the inhibition of active escape responses caused by the tethers (Barbeau \& Scheibling 1994b, Zimmer-Faust et al. 1994). Barbeau \& Scheibling (1994b) showed that tethering does not affect the predation rate of crabs, because of the generally passive responses of scallops when encountered by crabs. This is corroborated in our study by the similar results on size-specific vulnerability to crabs in our tethering experiment and in our cage experiments on untethered scallops (Figs. $1 \& 3$ ). Tethering experiments may overestimate predation rates of asteroids because the tethers likely limit the scallop's flight response (Barbeau \& Scheibling 1994b). Therefore, our results on vulnerability to asteroid predators may be biased.

\section{Phylogenetic origin of crevice use by Chlamys islandica}

Chlamys islandica is one of the largest species of its genus and attains $110 \mathrm{~mm}$ in shell height in the northern Gulf of St. Lawrence (Giguère et al. 1990, Arsenault \& Himmelman 1996). Small byssate species of Chlamys generally occur in crevices under rocks or other benthic structures whereas larger species live in exposed habitats (Kauffman 1969, Gilkinson \& Gagnon 1991). The Iceland scallop exhibits both life habits during its ontogeny, being mostly cryptic at small sizes and changing to exposed habits with increasing size (Arsenault \& Himmelman 1996, this study). The significance of crevice use by Chlamys spp. is poorly understood but has been suggested to be an adaptation to avoid strong currents and wave action (Gilkinson \& Gagnon 1991). Our study is the first to show that use of crevices by scallops decreases predation risk. This suggests that crevice use may have evolved in response to predation pressure. We believe that size-related changes in the frequency of refuge use by Iceland scal- lops result from behavioural habitat selection or from decreasing refuge availability with increasing scallop size. Another, although less probable cause, could be selective predation on exposed scallops. Because the mortality rate is much greater for exposed than sheltered scallops, the number of exposed scallops should decrease more rapidly than that of scallops in crevices. This would lead to a rapid increase in the proportion of scallops found in refuges with increasing size, the opposite of the observed pattern (Fig. 2).

\section{Size-related changes in the frequency of refuge use}

When vulnerability to predators changes with size, prey often adjust their antipredator defenses to current levels of predation risk (Lima \& Dill 1990). That the frequency of refuge use by Iceland scallops is positively correlated with their vulncrability to crab and asteroid predators (Spearman's rank correlation, $\mathrm{r}_{\mathrm{s}}=0.70, \mathrm{p}=$ 0.009 for crabs and $r_{\varsigma}=0.62, p=0.02$ for asteroids, Fig. 4) suggests that size-related changes in refuge use are related to predation risk. Use of habitats which minimize predation risk often place prey in less

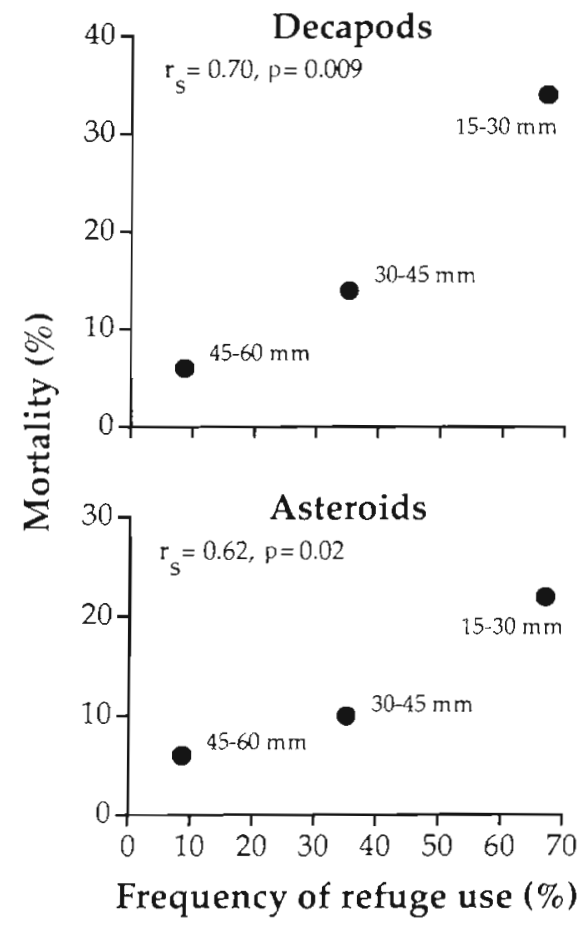

Fig. 4. Chlamys islandica. Relation between the frequency of refuge use and vulnerability to crab and asteroid predators, as determined by tethering experiments during the summer of 1994, for different sized juvenile Iceland scallops at lile du Fantome. Spearman rank correlation coefficients and their associated probability values were calculated using all 5 values for each size class ( $n=15$ ). Mean values of vulnerability are presented for clarity 
favourable conditions for growth by limiting feeding opportunities, for example placing them in situations where food quantity or quality is reduced (Werner 1988, Lima \& Dill 1990). Thus, when selecting habitats, prey may be confronted with a trade-off between survival and growth opportunities (Werner et al. 1983, Werner \& Hall 1988, Ambrose \& Irlandi 1992). When habitat-specific growth and mortality rates vary with prey size, prey often change habitats as they increase in size to minimize this trade-off (Werner 1988).

It is not known whether refuge use by Iceland scallops involves a trade-off between feeding opportunities and avoiding predators. Scallops filter-feed on seston (suspended food particles in the water column), and flow characteristics as well as seston concentration and composition are reported to affect the efficiency of their feeding (Bricelj \& Shumway 1991). If scallops in crevices are exposed to less favourable conditions for growth then a trade-off would be expected. We are presently examining if crevice use affects feeding opportunities by comparing the growth rate of juvenile scallops in crevices and on exposed surfaces.

Acknowledgements. We are grateful to S. Blanchet, M. Vaugeois and $F$. Tétreault for their aid with the field work and to $\mathrm{R}$. Rochette and J. N. McNeil for insightful comments on the manuscript. This study was supported by NSERC operating grants to J.H.H. and NSERC and FCAR scholarships to D.J.A.

\section{LITERATURE CITED}

Ambrose WGJ, Irlandi EA (1992) Height of attachment on seagrass leads to trade-off between growth and survival in the bay scallop Argopecten irradians. Mar Ecol Prog Ser 90:45-51

Arsenault DJ, Himmelman JH (1996) Ontogenetic habitat shifts in the Iceland scallop, Chlamys islandica (Müller, 1776), in the northern Gulf of St. Lawrence. Can J Fish Aquat Sci (in press)

Barbeau MA, Scheibling RE (1994a) Behavioral mechanisms of prey size selection by sea stars (Asterias vulgaris Verrill) and crabs (Cancer irroratus Say) preying on juvenile sea scallops (Placopecten magellanicus (Gmelin)). J Exp Mar Biol Ecol 180:103-136

Barbeau MA, Scheibling RE (1994b) Procedural effects of prey tethering experiments: predation of juvenile scallops by crabs and sea stars. Mar Ecol Prog Ser 111:305-310

Barbeau MA, Scheibling RE, Hatcher BG, Taylor LH, Hennigar AW (1994) Survival analysis of tethered juvenile sea scallops Placopecten magellanicus in field experiments: effects of predators, scallop size and density, site and season. Mar Ecol Prog Ser 115:243-256

Bérubé M (1989) Partage des ressources entre le crabe tourteau, Cancer irroratus Say, et le crabe araignée, Hyas araneus Linnée, au nord du golfe du Saint-Laurent. MSc thesis, Département de Biologie, Université Laval, Québec

Brand AR (1991) Scallop ecology: distributions and behaviour. In: Shumway SE (ed) Scallops: biology, ecology and aquaculture. Elsevier, New York, p 517-584

Bricelj VM, Shumway S (1991) Physiology: energy acquisition and utilization. In: Shumway SE (ed) Scallops: biology, ecology and aquaculture. Elsevier, New York, p 305-346 Brun E (1971) Predation of Chlamys islandica (O. F. Müller) by eiders Somateria spp. Astarte 4:23-29

Ekman S (1953) Zoogeography of the sea. Sidwick and Jackson, London

Elner RW, Jamieson GS (1979) Predation of sea scallops, Placopecten magellanicus, by the rock crab, Cancerirroratus, and the American lobster, Homarus americanus. J Fish Res Bd Can 36:537-543

Flecker AS (1992) Fish predation and the evolution of invertebrate drift periodicity: evidence from neotropical streams. Ecology 73:438-448

Giguère M, Nadeau A. Légaré B (1990) Distributıon et biologie du pétoncle d'Islande (Chlamys islandica) de la CôteNord du golfe du Saint-Laurent. Can Tech Rep Fish Aquat Sci 1748:1-28

Gilkinson KD, Gagnon JM (1991) Substratum associations of natural populations of Iceland scallops, Chlamys islandica Müller 1776, on the northeastern Grand Bank of Newfoundland. Amer Malacol Bull 9:59-67

Juanes F (1992) Why do decapod crustaceans prefer small sized molluscan prey? Mar Ecol Prog Ser 87:239-249

Kauffman EG (1969) Form, function and evolution. In: Moore $\mathrm{RC}$ (ed) Treatise on invertebrate paleontology. The Geological Society of America and the University of Kansas, New York, p N130-N205

Kirk RE (1982) Experimental design: procedures for the behavioral sciences. Brooks/Cole, Belmont, CA

Lake NCH, Jones MB (1987) Crab predation on scallop (Pecten maxinus) and its implication for scallop cultivation. J Mar Biol Ass UK 67:55-64

Land MF (1984) Crustacea. In: Ali MA (ed) Photoreception and vision in invertebrates. Plenum Press, New York, p 401-438

Lima SL, Dill LM (1990) Behavioral decisions made under the risk of predation: a review and prospectus. Can J Zool 68: 619-640

Manly BFJ (1991) Randomization and Monte Carlo methods in biology. Chapman and Hall, New York

Manuel JL, Dadswell MJ (1991) Swimming behavior of juvenile giant scallop, Placopecten magellanicus, in relation to size and temperature. Can J Zool 69:2250-2254

Peterson CH, Black R (1994) An experimentalist's challenge: when artifacts of intervention interact with treatments. Mar Ecol Prog Ser 111:289-297

Pohle DG, Bricelj VM, Garcia-Esquivel Z (1991) The eelgrass canopy: an above-bottom refuge from benthic predators for juvenile bay scallops Argopecten irradians. Mar Ecol Prog Ser 74:47-59

Roa R (1992) Design and analysis of multiple-choice feedingpreference experiments. Oecologia 89:509-515

Rochette R, Hamel JF, Himmelman JH (1994) Foraging strategy of the asteroid Leptasterias polaris: role of prey odors, current and feeding status. Mar Ecol Prog Ser 106: $93-100$

Sih A (1985) Evolution, predator avoidance, and unsuccessful predation. Am Nat 125:153-157

Sih A (1987) Predators and prey lifestyles: an evolutionary overview. In: Kerfoot WC, Sih A (eds) Predation: direct and indirect impacts on aquatic communities. University Press of New England, Hanover, p 203-224

Sloan NA, Campbell AC (1982) Perception of food. In: Jangoux $M$, Lawrence JM (eds) Echinoderm nutrition. AA. Balkema, Rotterdam, p 3-23

Sponaugle S, Lawton P (1990) Portunid crab predation on juvenile hard clams: effects of substrate type and prey density. Mar Ecol Prog Ser 67:43-53 
Stokesbury KDE, Himmelman JH (1995) Biological and physical variables associated with aggregations of the giant scallop Placopecten magellanicus. Can J Fish Aquat Sci 52:743-753

Thomas GE, Gruffydd LD (1971) The types of escape reactions elicited in the scallop Pecten maximus by selected sea-star species. Mar Biol 10:87-93

Tikkanen P, Muotka T, Huhta A (1994) Predator detection and avoidance by lotic maylly nymphs of different size. Oecologia 99:252-259

Weissburg MJ, Zimmer-Faust RK (1993) Life and death in moving fludds: hydrodynamic effects on chemosensorymediated predation. Ecology 74:1428-1443

Werner EE (1988) Size, scaling, and the evolution of complex Life-cycles. In: Ebenmen B, Persson L (eds) Size-structured populations. Springer-Verlag, Berlin, p 60-81

Werner EE, Hall DJ (1988) Ontogenetic habitat shifts in bluegill: the foraging rate-predation risk trade-off. Ecology 69:1352-1366

Werner EE, Mittelbach GG, Hall DJ, Gilliam JF (1983) Experimental tests of optimal habitat use in fish: the role of rela-

This article was submitted to the editor tive habitat profitability. Ecology 64:1525-1539

Wiborg KF (1963) Some observations on the Iceland scallop Chlamys islandica (Müller) in Norwegian waters. Fiskeri Dir Skr Ser Havunders 13:38-53

Wilkens LA (1991) Neurobiology and behavior of the scallop. In: Shumway SE (ed) Scallops: biology, ecology and aquaculture. Elsevier, New York, p 429-469

Williamson CE (1993) Linking predation risk models with behavioural mechanisms: identifying population bottlenecks. Ecology 74:320-331

Winter MA, Hamilton PV (1985) Factors influencing swimming in the Bay scallop. Argopecten irradians (Lamarck, 1819). J Exp Mar Biol Ecol 88:227-242

Zar JH (1984) Biostatistical analysis. Prentice-Hall, Englewood Cliffs

Zimmer-Faust RK (1989) The relation between chemoreception and foraging behaviour in crustaceans. Limnol Oceanogr 34:1367-1374

Zimmer-Faust RK, Fielder DR, Heck KLJ, Coen LD, Morgan SG (1994) Effects of tethering on predatory escape by juvenile blue crabs. Mar Ecol Prog Ser 111:299-303

Manuscript first received: April 15, 1996

Revised version accepted: June 5, 1996 